\title{
Effects of insect cadavers infected by Heterorhabditis bacteriophora and Steinernema diaprepesi on Meloidogyne incognita parasitism in pepper and summer squash plants
}

\author{
Eleodoro E. Del Valle ${ }^{1,3}$, Paola Lax ${ }^{2,3}$, Juan Rondán Dueñas ${ }^{4}$, and Marcelo E. \\ Doucet $^{2,3}$ \\ ${ }^{1}$ Facultad de Ciencias Agrarias, Universidad Nacional del Litoral, Kreder 2805, C.P. 3080HOF, Esperanza, \\ Santa Fe, Argentina. \\ ${ }^{2}$ Laboratorio de Nematología, Centro de Zoología Aplicada, Jardín Zoológico, Rondeau 798, C.P. \\ X5000AVP, Córdoba, Argentina. \\ ${ }^{3}$ Consejo Nacional de Investigaciones Científicas y Técnicas (CONICET), Av. Rivadavia 1917, C.P. \\ C1033AAJ, Ciudad Autónoma de Buenos Aires, Argentina. \\ ${ }^{4}$ Laboratorio de Biología Molecular, Pabellón CEPROCOR, Santa María de Punilla, X5164 Córdoba, Argentina.
}

\begin{abstract}
E. E. Del Valle, P. Lax, J. Rondán Dueñas, and M. E. Doucet. 2013. Effects of insect cadavers infected by Heterorhabditis bacteriophora and Steinernema diaprepesi on Meloidogyne incognita parasitism in pepper and summer squash plants. Cien. Inv. Agr. 40(1):109-118. The effects of insect cadavers infected with three isolates of Heterorhabditis bacteriophora and one isolate of Steinernema diaprepesi on a population of Meloidogyne incognita in pepper (Capsicum annuum) and summer squash (Cucurbita maxima) were evaluated in greenhouse experiments carried out in Santa Fe (Argentina). Insect cadavers were obtained for the experiments from last instar larvae of Galleria mellonella and Tenebrio molitor that had been infected with entomopathogenic nematodes. Two six-day-old insect cadavers per pot were placed below the soil surface, and the soil was inoculated with 100 second-stage juveniles of $M$. incognita. Sixty days after inoculation, the following parameters were recorded for each plant: number of leaves; dry weight of aerial parts; numbers of galls, egg masses and eggs; and numbers of galls, egg masses and eggs $\mathrm{g}^{-1}$ of root fresh matter. In pepper, the only variable affected by the infected cadavers with respect to control was the number of eggs in the treatment involving T. molitor cadavers infected with the H. bacteriophora isolate Rama Caída. In summer squash, several treatments using infected cadavers resulted in a decrease in the numbers of galls and egg masses. Only the treatment involving G. mellonella cadavers infected with the H. bacteriophora isolate Rama Caída proved to be efficient in reducing the number of $M$. incognita eggs. Our results indicated that the application of insect cadavers infected with the entomopathogenic nematodes studied might reduce $M$. incognita damage in pepper and summer squash plants.
\end{abstract}

Key words: Biological control, entomopathogenic nematodes, insect host cadavers.

\section{Introduction}

Root-knot nematodes (Meloidogyne spp.) are plant parasites that cause serious losses to economically

Received July 7, 2012. Accepted January 29, 2013. Corresponding author: edelvalle@fca.unl.edu.ar important crops (Koenning et al., 1999). The major strategy for the control of these organisms in horticultural crops in recent decades has been the use of chemical products, especially methyl bromide (Halbrendt and LaMondia, 2004). However, the use of methyl bromide was banned 
and/or restricted in several countries due to the environmental damage that it produces and its impact on human health, thus generating the need for new, environmentally friendly alternatives (Schafer, 1999). Accordingly, treatment with entomopathogenic nematodes (EPNs) is regarded as an alternative for the management of plantparasitic nematodes (Grewal et al., 2005).

Insect-parasitic (entomopathogenic) nematodes belong to the genera Heterorhabditis and Steinernema (Nematoda: Heterorhabditidae and Steinernematidae). Infective juveniles (IJs) search for a host, penetrate it through natural openings (mouth, anus or spiracles) or through the cuticle (Poinar, 1990). Once inside the host hemocoel, IJs release a symbiotic bacterium from their digestive tract. Steinernema species are associated with bacteria of the genus Xenorhabdus, whereas Heterorhabditis species are associated with bacteria of the genus Photorhabdus (Boemare et al., 1993; Thomas and Poinar, 1979). Infected insects usually die of septicemia approximately $48 \mathrm{~h}$ after infection (Akhurst and Boemare, 1990; Burman, 1982). Nematodes feed on the bacteria and digested tissues and complete one to three generations within the host until IJs emerge into the soil (Poinar, 1990).

The interaction between EPNs and plant-parasitic nematodes has been documented previously (Lewis and Grewal, 2005). Previous studies using EPNs did not find any definitive results in terms of their action against nematodes of the genus Meloidogyne (Fallon et al., 2002; Molina et al., 2007; Shapiro-Ilan et al., 2006a). However, several cases of suppressive action on $M$. incognita have been reported. Lewis et al. (2001) demonstrated that the use of IJs of Steinernema feltiae (Filipjev) significantly reduced the number of galls and eggs in tomato plants, even affecting egg hatching. In experiments conducted in growth chambers and a greenhouse, Pérez and Lewis (2002) found that IJs of H. bacteriophora, Steinernema riobrave
(Cabanillas, Poinar and Raulston) and S. feltiae reduced parasitism of $M$. incognita in tomato plants. Moreover, M. incognita was suppressed by IJs of Steinernema glaseri (Steiner) in an experiment evaluating application doses under greenhouse conditions.

Most of the works conducted until now have been based on the application of IJs of EPNs in aqueous suspension (Jagdale et al., 2002; Molina et al., 2007; Perry et al., 1998; Smitley et al., 1992). The use of this method has some disadvantages, such as IJs formulation, decrease of infectivity, survival of IJs during storage, transportation difficulties, and the need for adequate irrigation equipment (Grewal, 2002).

The use of EPN-infected insect cadavers provides an option for the control of root-knot nematodes because they lack some of the disadvantages of aqueous suspensions (Bruck et al., 2005; Creighton and Fassuliotis, 1985; Shapiro-Ilan et al., 2010; 2012). Infected insect cadavers are placed below the soil surface, and IJs emerge in the same environment where the target organisms are found. In laboratory assays, the use of this mode of EPN application has been shown to result in greater infectivity to insect hosts and increased survival and dispersal capacity than aqueous suspensions (Pérez et al., 2003; Shapiro and Glazer, 1996; Shapiro-Ilan and Lewis, 1999). Similar results were obtained in greenhouse experiments. Infective juveniles that had emerged from the cadavers of Tenebrio molitor infected with Heterorhabditis indica (Poinar, Karunaka and David) Hom1 caused a greater decrease in the survival of Diaprepes abbreviatus (Linnaeus) than IJs applied in aqueous suspensions (ShapiroIlan et al., 2003). In the same work, the authors found similar results regarding the control of Otiorhynchus sulcatus (Fabricius) 7 days after the application of T. molitor (Linnaeus) cadavers infected with Heterorhabditis bacteriophora (Poinar) Oswego. 
Suppression of plant-parasitic nematodes using infected cadavers has been reported by Jagdale and Grewal (2008), who studied the efficacy of preventive and curative applications of infective cadavers of $S$. carpocapsae (Weiser) for the management of Aphelenchoides fragariae (Ritzema Bos) in plants of Hosta spp.; the authors attributed the observed suppression to toxins produced by the entomopathogens and/or their symbiotic bacteria. The secondary metabolites 3,5-dihydroxy-4isopropylstilbene (DST) and indole, which are obtained from filtrates of $P$. luminescens, exhibit nematicidal properties. Second-stage juveniles of $M$. incognita were affected by indole, and both components inhibited egg hatching in that species (Hu et al., 1999). Hatching inhibition is most likely related to the fact that anion transporters act as target sites for blockers and DST in nematodes, thereby altering physiological processes through voltage-gated chloride channels, resulting in nematode and egg mortality (Boina et al., 2008). In addition, ammonia, which is produced by symbiotic bacteria in the host, exhibits nematicidal activity (Grewal et al., 1999).

Variable and/or confusing results about the EPNsMeloidogyne spp. interaction have also been reported in studies involving the application of IJs (Fallon et al., 2002; 2004; Molina et al., 2007; Pérez and Lewis, 2004). Hence, knowledge of the suppressive effect of local EPN isolates applied as insect cadavers on $M$. incognita is of great importance. The aim of the present work was to determine the effect of insect cadavers infected with three local isolates of $H$. bacteriophora and one of Steinernema diaprepesi (Nguyen and Duncan) on a population of $M$. incognita in pepper (Capsicum annuum Linnaeus) and summer squash (Cucurbita maxima Duch.). We hypothesize that the application of cadavers infected with local isolates of $H$. bacteriophora and $S$. diaprepesi would reduce $M$. incognita parasitism in pepper and summer squash.

\section{Materials and methods}

\section{Nematodes and infected cadavers}

Three Argentinean isolates of $H$. bacteriophora Rama Caída (Rama Caída, Mendoza), Jn (Recreo, Santa Fe) and Mo (Ángel Gallardo, Santa Fe) and one isolate of $S$. diaprepesi (Santa Rosa de Calchines, Santa Fe) were used as EPNs. Nematodes were multiplied on larvae of the greater wax moth, Galleria mellonella (Lepidoptera: Pyralidae) at $25{ }^{\circ} \mathrm{C}$, following the procedure described by Woodring and Kaya (1988). Third-stage juveniles were harvested from modified White traps (Kaya and Stock, 1997) and stored at $16{ }^{\circ} \mathrm{C}$ until use. G. mellonella larvae were reared on the diet formulated by Eischen and Dietz (1990), and larvae of T. molitor (Coleoptera: Tenebrionidae) were fed with wheat bran.

Insect hosts were infected in Petri dishes $(90 \mathrm{~mm}$ in diameter) lined with filter paper to obtain insect cadavers. Last-instar G. mellonella or T. molitor larvae were exposed to $100 \mathrm{IJs}$ of each isolate. The Petri dishes were incubated at $25{ }^{\circ} \mathrm{C}$ for 4 days, and infected cadavers were subsequently transferred to new Petri dishes lined with dry filter paper for a further two days of incubation to allow the development of typical signs of EPN infection (the cadavers become flaccid and exhibit a color change) (Woodring and Kaya, 1988).

The population of $M$. incognita was obtained from pepper and summer squash maintained under greenhouse conditions and inoculated with nematodes from the locality of Santa Rosa de Calchines. These plant species were chosen because they are severely parasitized by M. incognita and of regional economic importance. Second-stage juveniles were obtained by incubation of egg masses of $M$. incognita in a wet chamber under laboratory conditions. 


\section{Greenhouse experiments}

One week after germination, seedlings of pepper, cultivar K. Resistant Giant (Nasco Seed Co.), and of summer squash (Cucurbita maxima var. zapallito (Carr.) Millán), cultivar Nacional (CAPS), were transplanted into pots (10 $\mathrm{cm}$ in diameter) containing $700 \mathrm{~cm}^{3}$ of sterile soil $(1.1 \%$ organic matter; $\mathrm{pH}: 7.1$; clay: $6 \%$, silt: $8 \%$ and sand: $87 \%$ ). Two days after transplanting, EPN-infected cadavers were applied. The treatments were as follows: (i) control; (ii) carbofuran $25 \mathrm{mg} \mathrm{L}^{-1}$ as a chemical control; (iii) T. molitor cadavers infected with H. bacteriophora Rama Caída (HbRCT); (iv) $T$. molitor cadavers infected with $H$. bacteriophora Jn (HbJnT); (v) T. molitor cadavers infected with H. bacteriophora Mo (HbMoT); (vi) T. molitor cadavers infected with $S$. diaprepesi (SdT); (vii) G. mellonella cadavers infected with $H$. bacteriophora Rama Caída (HbRCG); (viii) $G$. mellonella cadavers infected with H. bacteriophora Jn (HbJnG); (ix) G. mellonella cadavers infected with $H$. bacteriophora Mo ( $\mathrm{HbMoG})$; and (x) G. mellonella cadavers infected with $S$. diaprepesi (SdG).

In treatments involving the use of infected cadavers, two cadavers were added per pot. The cadavers were buried $2 \mathrm{~cm}$ below the soil surface and 2.5 $\mathrm{cm}$ from the stem, diametrically opposite each other. The insect cadavers used were infected 6 days before application (Del Valle et al., 2008). Five days after the introduction of the cadavers into the pots, the plants were inoculated by adding an aqueous suspension containing 100 J2s of $M$. incognita with a micropipette. The suspension was poured into holes made in the soil around the plant stem. The plants were watered as needed. During the experimental period, the mean temperature was maintained at $18.1^{\circ} \mathrm{C}$ to ensure normal development and multiplication of nematodes inside the hosts (Grewal et al., 2006).

The results were evaluated 60 days after $M$. incognita inoculation. The following variables were recorded for each plant: number of leaves, dry weight of aerial parts, number of galls, number of egg masses, number of eggs, number of galls/g of root fresh matter, number of egg masses $\mathrm{g}^{-1}$ of root fresh matter, and number of eggs $\mathrm{g}^{-1}$ of root fresh matter. Total numbers of galls, egg masses and eggs were counted under a stereoscopic microscope. The eggs were removed from the roots using the procedure described by Hussey and Barker (1973).

The experiment was conducted using a completely randomized design with six replications. The entire experiment was performed twice. No significant interactions between trials $(\alpha=0.05)$ were detected; therefore, pooled data were subjected to analysis of variance (ANOVA). The averages of experiments are shown in Tables 1 and 2. Means were compared among treatments using Tukey's HDS test at $\mathrm{P} \leq 0.05$ probability.

\section{Results}

\section{Experiments using pepper plants}

The results observed in pepper plants are presented in Table 1. The use of cadavers infected with EPN isolates did not show significant differences from control treatment with respect to the number of leaves per plant or the dry weight of aerial parts $\left(F_{9,110}=4.54, P \leq 0.0001\right.$ and $F_{9,110}=4.06, P \leq 0.0002$, respectively). The treatment with carbofuran was the only treatment to exhibit statistically significant differences from the control with respect to the number of galls. However, treatments HbRCT, HbRCG, $\mathrm{HbMoG}$ and $\mathrm{SdG}$ did not differ from the chemical treatment $\left(\mathrm{F}_{9,110}=5.97, \mathrm{P} \leq 0.0001\right)$. Carbofuran application caused a significant reduction in the number of egg masses in pepper plants, without showing significant differences from HbRCT, HbRCG, HbMoG or $\mathrm{SdG}\left(\mathrm{F}_{9,110}=\right.$ 5.47; $\mathrm{P} \leq 0.0001)$. The number of $M$. incognita eggs produced by nematodes in the root systems of plants treated with carbofuran and HbRCT was significantly lower than that observed for the control $\left(\mathrm{F}_{9,110}=7.17, \mathrm{P} \leq 0.0001\right)$. 


\section{Experiments using summer squash}

The treatments evaluated did not significantly affect the number of leaves per plant $\left(\mathrm{F}_{9,110}=0.56\right.$, $\mathrm{P} \leq 0.8242$ ). Plants treated with HbRCT showed the highest value of dry weight of aerial parts among treatments $\left(\mathrm{F}_{9,110}=3.82, \mathrm{P} \leq 0.0003\right)$. Infected cadavers significantly decreased the numbers of galls and egg masses $\left(\mathrm{F}_{9,110}=3.88, \mathrm{P} \leq 0.0003\right.$ and $\mathrm{F}_{9,110}=3.88, \mathrm{P} \leq 0.0003$, respectively). HbJnG did not affect the variables mentioned, and HbRCT did not differ from the control in terms of the number of egg masses per plant. HbRCG was the only treatment that differed from control in reducing the total number of eggs per plant $\left(\mathrm{F}_{9,110}=3.89, \mathrm{P} \leq 0.0003\right)$. There were no statistically significant differences among treatments with respect to the number of galls/g of root fresh weight and the number of egg masses/g of root fresh weight $\left(\mathrm{F}_{9,110}=4.45, \mathrm{P} \leq 0.0001\right.$ and $\mathrm{F}_{9,110}=$ $3.09, \mathrm{P} \leq 0.0024$, respectively). The negative control was statistically similar to treatments HbRCT, HbJnT, HbMoT, SdT and HbRCG in terms of the number of eggs/g of root fresh weight $\left(\mathrm{F}_{9,110}=\right.$ $6.49, \mathrm{P} \leq 0.0001)$. The results of this experiment are presented in Table 2 .

\section{Discussion}

The use of EPN-infected cadavers of G. mellonella and T. molitor had different effects on pepper and summer squash. In pepper, the only variable affected by infected cadavers with respect to the control was the number of eggs in the treatment involving T. molitor cadavers infected with $H$. bacteriophora Rama Caída. In summer squash, several treatments using infected cadavers reduced the number of galls and egg masses. Only the treatment including G. mellonella cadavers infected with $H$. bacteriophora Rama Caída proved efficient in reducing the number of $M$. incognita eggs.

The lack of efficacy of EPN aqueous suspensions for the control of $M$. incognita has also been reported. For example, Heterorhabditis megidis
(Poinar, Jackson and Klein) did not produce any effects on tomato, even at high doses (Pérez and Lewis, 2004). In the only work that studied plants of the family Cucurbitaceae, the species $S$. riobrave and $H$. bacteriophora were not effective in the control of zucchini squash (Cucurbita pepo Linnaeus) (Riegel et al., 1998). The results presented here demonstrate that the action of EPNs may reduce damage caused by $M$. incognita in summer squash plants.

Determining the activity of metabolites and toxins produced by the symbiotic bacteria studied was beyond the scope of the present work; however, such activity may have affected our results. The action of metabolites and toxins might explain, at least in part, the suppression observed in the treatments including $H$. bacteriophora isolate Rama Caída. In addition, Grewal et al. (1999) confirmed that $G$. mellonella cadavers infected with $H$. bacteriophora had repelling effects on juveniles of $M$. incognita and that allelochemicals produced by symbiotic bacteria are plant-parasitic nematode antagonists.

In our research, two cadavers per pot were applied, similar to a greenhouse trial conducted by Shapiro-Ilan et al. (2006b), who demonstrated that the application of two T. molitor cadavers infected with $S$. riobrave reduced the number of egg masses of Meloidogyne partityla (Kleynhans) in pecan seedlings. Larvae of G. mellonella and T. molitor were used as insect hosts in the present work due to the great commercial potential of this application method (Deol et al., 2011; ShapiroIlan et al., 2001, 2010). The host species did not show a marked influence on the suppression of $M$. incognita with the EPNs used. Both insect hosts might be employed in EPN application. T. molitor cadavers have a more rigid cuticle than those of $G$. mellonella and therefore exhibit greater resistance to physical damage during manipulation and transportation (Shapiro-Ilan et al., 2010). However, the formulation of $G$. mellonella cadavers is an alternative that facilitates handling (Del Valle et al., 2009; Shapiro-Ilan et al., 2001). 


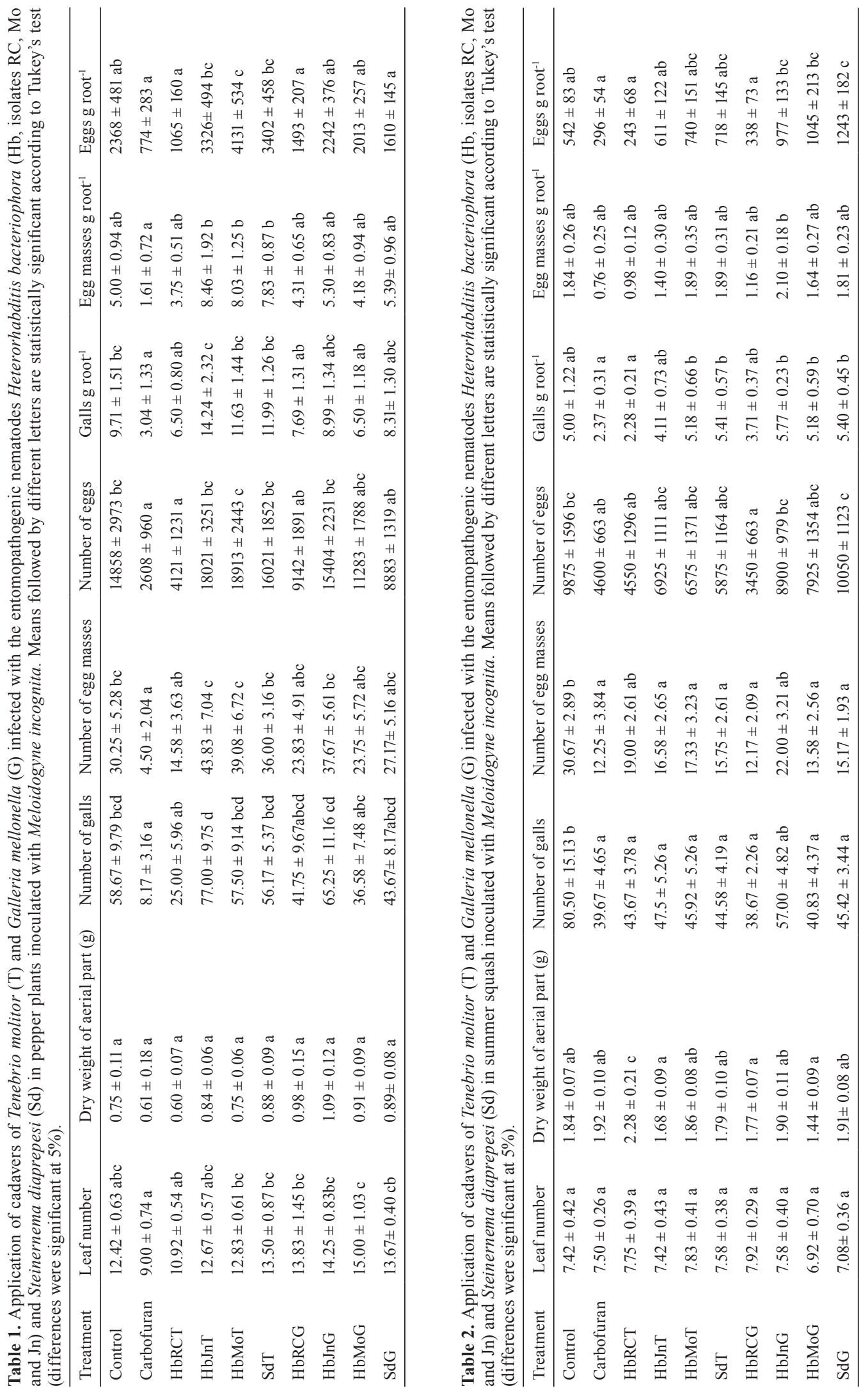


Inconsistent results were also reported by ShapiroIlan et al. (2006a) in an assessment of the effect of the application of $T$. molitor cadavers infected with $S$. feltiae and $S$. riobrave on $M$. partityla. Further research is necessary to elucidate the reasons why the efficacy observed in laboratory assays is frequently not found in greenhouse or field experiments.

In the present work, we observed a marked difference in the suppression of $M$. incognita among the three isolates of $H$. bacteriophora evaluated. The performance of each isolate may be associated with metabolites produced by their symbiotic bacteria, which differ in quality and quantity among isolates (Webster et al., 2002). Heterorhabditis bacteriophora Rama Caída produced the greatest reduction in the parasitism of $M$. incognita in pepper and summer squash and will require field investigations for commercial application.

The species $S$. diaprepesi did not exhibit potential for the suppression of $M$. incognita in pepper and summer squash, although IJs of this species exhibited increased survival in the soil than $H$. bacteriophora IJs (Shapiro-Ilan et al., 2006b). Pérez and Lewis (2004) suggested that Steinernema species might be more effective in the suppression of root-knot nematodes than $H$. bacteriophora because of their greater capacity to penetrate roots and to release symbiotic bacteria inside them. Within roots, the bacteria would release allelochemicals that are toxic and repellent to Meloidogyne spp. (Grewal et al., 1999). Steinernema diaprepesi IJs remained near the roots in pepper and summer squash plants. The greatest efficacy of steinernematids suggested by Pérez and Lewis (2004) was not evident in our experiments. Additional studies are necessary to determine the behavior of $S$. diaprepesi IJs and the action of their allelochemicals against root-knot nematodes parasitizing pepper and summer squash.

Our results indicated that the application of insect cadavers infected with the EPNs studied might reduce $M$. incognita damage in pepper and summer squash plants. However, further studies are required to determine their efficacy in field applications.

\section{Acknowledgments}

The present work was funded by the program Curso de Acción para la Investigación y el Desarrollo, CAI+D 2009 of the Universidad Nacional del Litoral.

\section{Resumen}

E.E. Del Valle, P. Lax, J. Rondán Dueñas y M.E. Doucet. 2013. Efecto de insectos cadáveres infectados por Heterorhabditis bacteriophora y Steinernema diaprepesi sobre el parasitismo de Meloidogyne incognita en plantas de pimiento y zapallito redondo de tronco. Cien. Inv. Agr. 40(1):109-118. El efecto de cadáveres de insectos infectados con tres aislados de Heterorhabditis bacteriophora y un aislado de Steinernema diaprepesi sobre una población de Meloidogyne incognita en plantas de pimiento (Capsicum annuum) y zapallito redondo de tronco (Cucurbita maxima) fue evaluado en experiencias de invernadero conducidas en Santa Fe (Argentina). Los cadáveres de insectos necesarios para la experiencia se obtuvieron infectando larvas de último estadio de Galleria mellonella y Tenebrio monitor con nematodos entomopatógenos. Dos cadáveres de seis días de infección se colocaron debajo de la superficie del suelo de macetas que fueron inoculadas con 100 juveniles de segundo estadio de $M$. incognita. A los sesenta días se registraron los siguientes parámetros en cada planta: número de hojas, peso seco de la parte aérea, número de agallas, masas de huevos 
y huevos, y número de agallas, masas de huevos y huevos $\mathrm{g}^{-1}$ de materia fresca radical. En pimiento, la única variable afectada por los cadáveres en relación al testigo fue el número de huevos de $M$. incognita en el tratamiento de cadáveres de $T$. molitor infectados con $H$. bacteriophora aislado Rama Caída. En zapallito redondo de tronco, varios tratamientos provocaron una disminución en el número de agallas y masas de huevos. Sólo la aplicación de cadáveres de G. mellonella infectados con H. bacteriophora aislado Rama Caída demostró ser eficiente en reducir el número de huevos de M. incognita. Nuestros resultados indicaron que la aplicación de cadáveres de insectos infectados con los nematodos entomopatógenos estudiados podría reducir los daños causados por M. incognita en plantas de pimiento y zapallito redondo de tronco.

Palabras clave: Cadáveres de insectos infectados, control biológico, nematodos entomopatógenos.

\section{References}

Akhurst R., and N.E. Boemare. 1990. Biology and taxonomy of Xenorhabdus. In: Gaugler R., and Kaya H.K. (eds.). Entomopathogenic nematodes in biological control. Boca Raton, FL, CRC Press. p. 75-87.

Boemare N.E., Akhurst R.J., and R.G. Mourant. 1993. Deoxyribonucleic acid relatedness between Xenorhabdus spp. (Enterobacteriaceae), symbiotic bacteria of entomopathogenic nematodes, with a proposal to transfer Xenorhabdus luminescens to a new genus Photorhabdus gen. nov. International Journal of Systematic Bacteriology 43:249-255.

Boina D.R., Lewis E.E., and J.R. Bloomquist. 2008. Nematicidal activity of anion transport blockers against Meloidogyne incognita, Caenorhabditis elegans, and Heterorhabditis bacteriophora. Pest Management Science 64:646-653.

Bruck D.J., Shapiro-Ilan D.I., and E.E. Lewis. 2005. Evaluation of application technologies of entomopathogenic nematodes for control of the black vine weevil, Otiorhynchus sulcatus. Journal of Economic Entomology 98:1884-1889.

Burman M. 1982. Neoplectana carpocapsae: a toxin production by axenic insect parasitic nematode. Nematologica 28:62-70.

Creighton C.S., and G. Fassuliotis. 1985. Heterorhabditis sp. (Nematoda: Heterorhabditidae): A nematode parasite isolated from the banded cucumber beetle Diabrotica balteata. Journal of Nematology 17:150-153.
Del Valle E.E., Dolinski C., Barreto E.L.S., and R.M. Souza. 2009. Effect of cadaver coatings on emergence and infectivity of the entomopathogenic nematode Heterorhabditis baujardi LPP7 (Rhabditida: Heterorhabditidae) and the removal of cadavers by ants. Biological Control 50:21-24.

Del Valle E.E., Dolinski C., Barreto E.L.S., and R.M. Souza. 2008. Efficacy of Heterorhabditis baujardi LPP7 (Nematoda: Rhabditida) applied in Galleria mellonella (Lepidoptera: Pyralidae) insect cadavers to Conotrachelus psidii, (Coleoptera: Curculionidae) larvae. Biocontrol Science and Technology 18:33-41.

Deol Y.S., Jagdale G.B., Cañas L., and P.S. Grewal. 2011. Delivery of entomopathogenic nematodes directly through commercial growing medium via the inclusion of infected host cadavers: A novel approach. Biological Control 58:60-67.

Eischen F.A., and A. Dietz. 1990. Improved culture techniques for mass rearing Galleria mellonella. Entomological News 101:123-128.

Fallon D.J., Kaya H.K., Gaugler R., and B.S. Sipes. 2002. Effects of entomopathogenic nematodes on Meloidogyne javanica on tomatoes and soybeans. Journal of Nematology 34:239-245.

Fallon D.J., Kaya H.K., Gaugler R., and B.S. Sipes. 2004. Effect of Steinernema feltiae-Xenorhabdus bovienii insect pathogen complex on Meloidogyne javanica. Nematology 6:671-680.

Grewal P.S. 2002. Formulation and application technology. In: Gaugler R. (ed.). Entomopathogenic nematology. CABI, Wallingford, UK. p. 265-287. 
Grewal P.S., Bornstein-Forst S., Burnell A.M., Glazer I., and G.B. Jagdale. 2006. Physiological, genetic, and molecular mechanisms of chemoreception, thermobiosis, and anhydrobiosis in entomopathogenic nematodes. Biological Control 38:54-65.

Grewal P.S., Ehlers R-U., and D.I. Shapiro-Ilan. 2005. Nematodes As Biocontrol Agents. CABI, U.K. 505 pp.

Grewal P.S., Lewis E.E., and S. Venkatachari. 1999. Allelopathy: A possible mechanism of suppression of plant-parasitic nematodes by entomopathogenic nematodes. Nematology 1:735-743.

Halbrendt J.M., and J.A. LaMondia. 2004. Crop Rotation And Other Cultural Practices. In: Chen, Z.X., Chen S.Y., and D.W. Dickson (eds.). Nematology, Advances and Perspectives Vol 2: Nematode Management and Utilization. CABI, Cambridge. p. 909-930.

Hu K., Li J., and J.M. Webster. 1999. Nematicidal metabolites produced by Photorhabdus luminescens (Enterobacteriaceae), bacterial symbiont of entomopathogenic nematodes. Nematology 1:457-469.

Hussey R.S., and K.R. Barker. 1973. A comparison of methods of collecting inocula of Meloidogyne spp. including a new technique. Plant Disease Report 57:1025-1028.

Jagdale G.B., and P.S. Grewal. 2008. Influence of the entomopathogenic nematode Steinernema carpocapsae infected host cadavers or their extracts on the foliar nematode Aphelenchoides fragariae on Hosta in the greenhouse and laboratory. Biological Control 44:13-23.

Jagdale G.B., Somasekhar N., Grewal P.S., and M.G. Klein. 2002. Suppression of plant-parasitic nematodes by application of live and dead infective juveniles of an entomopathogenic nematode, Steinernema carpocapsae, on boxwood (Buxus spp.). Biological Control 24:42-49.

Kaya H.K., and S.P. Stock. 1997. Techniques In Insect Nematology. In: Lacey, L.A. (ed.). Manual of techniques in insect pathology Biological Techniques Series. London, Academic Press. p. 281-324.
Koenning S.R., Overstreet C., Noling J.W., Donald P.A., Becker J.O., and B.A. Fortnum. 1999. Survey of crop losses in response to phytoparasitic nematodes in the United States for 1994. Journal of Nematology 31:587-618.

Lewis E.E., Grewal P.S., and S. Sardanelli. 2001. Interactions between the Steinernema feltiaeXenorhabdus bovienii insect pathogen complex and the root-knot nematode Meloidogyne incognita. Biological Control 21:55-62.

Lewis E.E., and P.S. Grewal. 2005. Interactions With Plant-Parasitic Nematodes. In: Grewal P.S., Ehlers R.-U., and D.I. Shapiro-Ilan (eds.). Nematodes as Biocontrol Agents. CABI, UK. p. 349-361.

Molina J.P., Dolinski C., Souza R.M., and E.E. Lewis. 2007. Effect of entomopathogenic nematodes (Rhabditida: Steinernematidae and Heterorhabditidae) on Meloidogyne mayaguensis Rammah and Hirschmann (Tylenchida: Meloidoginidae) infection in tomato plants. Journal of Nematology 39:338-342.

Pérez E.E., and E.E. Lewis. 2002. Use of entomopathogenic nematodes to suppress Meloidogyne incognita on greenhouse tomatoes. Journal of Nematology 34:171-174.

Pérez E.E., Lewis E.E., and D.I. Shapiro-Ilan. 2003. Impact of host cadaver on survival and infectivity of entomopathogenic nematodes (Rhabditida: Steinernematidae and Heterorhabditidae) under desiccating conditions. Journal of Invertebrate Pathology 82:111-118.

Pérez E.E., and E.E. Lewis. 2004. Suppression of Meloidogyne incognita and Meloidogyne hapla with entomopathogenic nematodes on greenhouse peanuts and tomatoes. Biological Control 30:336-341.

Perry R.N., Hominick W.M., Beane J., and B. Briscoe. 1998. Effects of the entomopathogenic nematodes, Steinernema feltiae and S. carpocapsae, on the potato cyst nematode, Globodera rostochiensis, in pot trials. Biocontrol Science and Technology 8: 175-180.

Poinar G.O. 1990. Biology And Taxonomy Of Steinernematidae. In: Gaugler R., and H.K. Kaya (eds.). Entomopathogenic Nematodes in Biological Control, CRC Press. FL. p. 23-61. 
Riegel C., Dickson D.W., Nguyen K.B., and G.C. Smart. 1998. Management of root-knot nematodes with entomopathogenic nematodes. Journal of Nematology Supplement 24:637-641.

Schafer K.S. 1999. Methyl Bromide Phase-out Strategies: A Global Compilation of Laws and Regulations, OzonAction Programme of the United Nations Environment Programme Division of Technology, Industry and Economics (UNEP TIE), Chatelaine, Geneva. 149 pp.

Shapiro D.I., and I. Glazer. 1996. Comparison of entomopathogenic nematode dispersal from infected hosts versus aqueous suspension. Environmental Entomology 25:1455-1461.

Shapiro-Ilan D.I., Nyczepir A.P., and E.E. Lewis. 2006a. Entomopathogenic nematodes and bacteria applications for control of the pecan root-knot nematode, Meloidogyne partityla, in the greenhouse. Journal of Nematology 38:449-454.

Shapiro-Ilan D.I., Stuart R., and C.W. McCoy. 2006b. A comparison of entomopathogenic nematode longevity in soil under laboratory conditions. Journal of Nematology 38:119-129.

Shapiro-Ilan D.I., and E.E. Lewis. 1999. Comparison of entomopathogenic nematode infectivity from infected hosts versus aqueous suspension. Environmental Entomology 28:907-911.

Shapiro-Ilan D.I., Han, R., and C. Dolinski. 2012. Entomopathogenic nematode production and application technology. Journal of Nematology 44:206-217.

Shapiro-Ilan D.I., Lewis E.E., and W.L. Tedders. 2003. Superior efficacy observed in entomopathogenic nematodes applied in infected-host cadavers compared with application in aqueous suspension. Journal of Invertebrate Pathology 83:270-272.

Shapiro-Ilan D.I., Lewis E.E., Behle R.W., and M.R. McGuire. 2001. Formulation of entomopathogenic nematode-infected-cadavers. Journal of Invertebrate Pathology 78:17-23.

Shapiro-Ilan D.I., Morales-Ramos J.A., Rojas M.G., and W.L. Tedders. 2010. Effects of a novel entomopathogenic nematode-infected host formulation on cadaver integrity, nematode yield, and suppression of Diaprepes abbreviatus and Aethina tumida. Journal of Invertebrate Pathology 103:103-108.

Smitley D.R., Warner F.W., and G.W. Bird 1992. Influence of irrigation and Heterorhabditis bacteriophora on plant-parasitic nematodes in turf. Journal of Nematology 24:637- 641.

Thomas G.M., and G.O. Poinar Jr. 1979. Xenorhabdus gen. nov., a genus of entomopathogenic and nematophilic bacteria of the family Enterobacteriaceae. International Journal of Systematic Bacteriology 29:352-360.

Webster J.M., Chen G., Hu K., and J. Li. 2002. Bacterial metabolites. In: Gaugler R. (ed.). Entomopathogenic nematology CABI, Wallingford, UK. p. 99-114.

Woodring J.L., and H.K. Kaya. 1988. Steinemematid and heterorhabditid nematodes: A handbook of techniques, Arkansas Agricultural Experiment Station, Fayetteville, AK. Series Bulletin 331. 